\title{
METAFORA RISK AND RETURN SEBAGAI DASAR PENGEMBANGAN BAITUL MAAL WA TAMWIL (BMT) YANG MANDIRI
}

\author{
Tyas D. Hascaryani \\ Asfi Manzilati \\ Nurman S. Fadjar \\ Fakultas Ekonomi \& Bisnis Universitas Brawijaya
}

\begin{abstract}
The purpose of this study is to find out how Baitul Maal Wa Tamwil (BMT) can develop their independence as microfinance institutions, based on the expansion of the nature and development (metaphor) risk \& return. With post positivism rationalistic approach, the results of this study are: (1) the risk faced by BMT in addition to financial risk (conventional), as well as more broadly in the form of guarantees(goodwill) and guarantee facilities of customer funds. 2) On the return, in addition to financial return (conventional) the meaning has expanded on customer loyalty, market expansion and social functioning of the BMT.
\end{abstract}

Keywords: metaphor, risk, return, independency

\section{A. LATAR BELAKANG}

Lembaga Keuangan Mikro (LKM) merupakan salah satu solusi dari kesulitan permodalan yang dihadapi Usaha Kecil dan Menengah. LKM lebih mengena di kalangan UKM daripada bank umum karena lebih bersifat fleksibel, misalnya dalam hal persyaratan dan jumlah pinjaman maupun keluwesan pada pencairan kredit. Hal ini merupakan salah satu indikator bahwa keberadaan lembaga keuangan mikro sesuai dengan kebutuhan pelaku UKM, yang umumnya membutuhkan pembiayaan sesuai skala dan sifat usaha kecil (Wijono, 2005:87). Bentuk kerjasama tersebut berupa pembiayaan bagi hasil (musyarakah dan mudharabah), serta jual beli dengan penundaan pembayaran dan penyertaan investasi (Widodo; dalam Zarida, 2004:182).

Salah satu bentuk LKM yang hadir di tengah kondisi yang menghimpit pelaku Usaha Kecil dan Menengah tersebut adalah Baitul Maal Wa Tamwil (BMT). Sebagai representasi lembaga mikro syariah, BMT dinilai sangat strategis dalam memberdayakan masyarakat kecil. Sistem kerjasama yang ditawarkan BMT bagi usaha Kecil dan Menengah mampu melayani usaha kecil dengan skala pinjaman yang ditentukan secara efisien dan menguntungkan kedua belah pihak, baik BMT sendiri maupun peminjam (Zarida, 2004:179).

Faktor lain yang mendorong kesesuaian BMT dalam membiayai sektor UKM dikarenakan hubungan BMT dengan nasabah bersifat personal. Hubungan yang dekat dengan nasabah dibutuhkan BMT karena dalam kerjasama bagi hasil yang dijalin mengandalkan kepercayaan. Kepercayaan tesebut hadir secara dua arah. Nasabah membutuhkan kepercayaan yang diberikan BMT agar dapat memperoleh pinjaman. Sebaliknya, untuk tumbuh dan berkembang, BMT 
membutuhkan kepercayaan dari calon nasabah. Dengan keunggulan yang dimiliki, semestinya operasional BMT bisa lebih mandiri baik dari sisi penghimpunan dana maupun penyalurannya. Namun saat ini kalangan BMT menghadapi beberapa persoalan bersifat internal maupun eksternal yang menghambat proses menuju kemandirian tersebut. Secara eksternal, persoalan yang dihadapi adalah regulasi dan sistem keuangan dimana BMT menjalankan operasionalnya. Terdapat kerumitan peraturan yang mengikat BMT, dan kerumitan tersebut menjadi hambatan bagi perkembangan BMT karena kurangnya pengawasan dan pelaporan (Sakai dan Marijan, 2008:2).

Secara internal, beberapa kelemahan BMT adalah pelayanan yang diberikan kepada nasabah masih belum dilakukan secara profesional, belum memiliki perlindungan simpanan nasabah seperti yang dimiliki Bank Umum. Kelemahan lain yang dimiliki BMT adalah unit cost yang dapat diberikan BMT kepada sektor riil relatif lebih mahal. Kelemahan-kelemahan yang dimiliki BMT tersebut menjadi akar penyebab ketidakmandirian BMT sebagai Lembaga Keuangan Mikro.

Mendasarkan pada lingkungan internal dan eksternal BMT juga peran penting yang dapat dikembangkan oleh BMT, maka dalam rangka pengembangan kemandirian BMT, menjadi penting untuk menelaah perluasan hakikat dan pengembangan risk \& return dari BMT.

\section{B. KAJIAN TEORITIS}

\section{Peran BMT pada Sektor Riil}

Keberadaaan BMT diharapkan dapat memberikan kontribusi yang nyata dalam pengembagan sektor ekonomi riil, terlebih bagi kegiatan usaha yang belum memenuhi segala persyaratan untuk mendapatkan pembiayaan dari Bank Umum. Perkembangan sektor ekonomi riil akan dapat berlangsung dengan cepat ketika didukung oleh tersedianya sumber dana yang memadai dan sesuai dengan nilai-nilai keadilan (Suhendi, 2010:9). Keberadaan BMT dengan sistem kerjasama yang tidak memberatkan dan persyaratan yang mampu dipenuhi pelaku UKM dalam permohonan pembiayaan bagi usaha mereka memberikan posisi penting bagi BMT di sektor riil.

BMT sebagai lembaga keuangan alternatif diartikan sebagai suatu lembaga pendanaan yang mengakar di tengah-tengah masyarakat, dimana proses penyaluran dananya dilakukan secara sederhana, murah dan cepat dengan prinsip keberpihakan kepada masyarakat kecil dan berazaskan keadilan. Dilihat dari prosedur pembiayaan dan jangkauan pelayanannya, BMT merupakan lembaga keuangan alternatif yang sangat efektif dalam melayani kebutuhan pembiayaan modal kerja jangka pendek yang sangat diperlukan pengusaha kecil mikro (Situmorang, 2010:21). BMT menyalurkan pada sektor riil (UMK) berdasarkan sistem syariah dengan sistem bagi hasil menggunakan akad mudharabah atau musyarakah menyebabkan kedua belah pihak (BMT dan UKM) mempunyai rasa tanggung jawab yang sama akan keberhasilan usaha, karena BMT dan UMK pada posisi yang sama sebagai partner.

\section{Peran Keperantaraan BMT pada Pembiayaan Sektor Perbankan}

Sebagaimana diatur dalam ketentuan perbankan dalam Undang Undang Republik Indonesia Nomor 21 Tahun 2008 Tentang Perbankan Syariah, pasal 1 butir 7, yang dimaksud dengan 
Bank Syariah adalah Bank yang menjalankan kegiatan usahanya berdasarkan prinsip syariah dan menurut jenisnya terdiri atas Bank Umum Syariah (BUS) dan Bank Pembiayaan Rakyat Syariah. Sedangkan BMT merupakan lembaga keuangan non bank yang juga berlandaskan syariah dalam operasionalnya. Arti dari prinsip syariah itu sendiri adalah aturan perjanjian berdasarkan hukum Islam antara bank (lembaga keuangan) dengan pihak lain untuk penyimpanan dana atau pembiayaan kegiatan usaha yang dinyatakan sesuai dengan syariah. Adapun jenis pembiayaan tersebut antara lain pembiayaan berdasarkan prinsip bagi hasil (Mudharabah), pembiayaan berdasarkan prinsip kemitraan penyertaan modal (Musyarakah), prinsip jual-beli barang dengan memperoleh keuntungan (Murabahah) atau pembiayaan modal berdasarkan prinsip sewa murni tanpa pilihan (ijarah) atau dengan adanya pilihan pemindahan kepemilikan atas barang yang disewa dari pihak bank oleh pihak lain (ijarah iqtina).

Pada saat ini, lembaga keuangan yang berlandaskan prinsip syariah sudah dikenal secara luas oleh masyarakat, namun sebagai lembaga keuangan yang kehadirannya relatif baru dibanding lembaga keuangan konvensional maka sumberdaya yang dimiliki juga masih terbatas. Keterbatasan tersebut termasuk dalam menyediakan infrastruktur seperti tempat pelayanan nasabah (misal: kantor, teknologi, sistem jaringan) dimana kondisi tersebut menyebabkan penetrasi pasar menjadi tidak maksimal.

Berhadapan dengan permasalahan penetrasi pasar tersebut, BUS melihat bahwa sektor riil dalam skala kecil dan mikro sangat cocok dengan skema pembiayaan yang ditawarkan. Namun terbentur pada kuantitas pelayanan yang bisa diberikan maka strategi yang paling efisien untuk mampu merambah ke sektor kecil mikro tersebut adalah dengan menggandeng lembaga keuangan mikro yang juga berlandaskan syariah, yang dalam hal ini BMT.

Melalui kerjasama dengan BMT, maka penetrasi pasar BUS semakin bisa menjangkau masyarakat luas dan tentu ini menguntungkan bagi pertumbuhan aset dan laba BUS. Sedangkan dari sisi BMT, kerjasama dengan BUS akan memberikan tambahan sumberdana sehingga pembiayaan yang ditawarkan juga semakin besar, yang tentunya ju0ga berakibat pada naiknya pendapatan BMT. Menilik pola kerjasama tersebut, baik BUS maupun BMT bisa mengunduh keuntungan bagi keberadaan masing-masing lembaga, baik berupa keuntungan finansial maupun non finansial seperti pembentukan reputasi di masyarakat.

\section{Modal Sosial Sebagai Faktor Unik dalam Operasional BMT}

Sebagai lembaga keuangan yang mempunyai kekhasan pada layanannya yang lebih personal, maka interaksi yang terjadi antara nasabah dengan lembaga keuangan (BMT) dalam kontrak pembiayaan maupun simpanan akan dipengaruhi oleh keberadaan modal sosial. Sebuah kontrak akan diulang ataukah sekali dan kemudian selesai juga akan mempertimbangkan modal sosial tersebut. Secara singkat, Lin (2002: 19) mendefinisikan modal sosial sebagai investasi pada hubungan sosial dengan pengembalian yang diharapkan (expected returns) di pasar.

Bourdieu (1983/1986:248 dalam Lin, 2002:22) membedakan tiga bentuk modal yaitu: modal ekonomi, modal kultural dan modal sosial. Ketiga bentuk modal tersebut saling mendukung dalam operasional semua jenis lembaga keuangan, hanya pada umumnya di lembaga keuangan konvensional yang menonjol adalah modal ekonomi. Namun tidak demikian halnya pada lembaga keuangan yang menggunakan prinsip profit/loss sharing atau return sharing terutama yang menggunakan akad syariah. Kontribusi modal sosial sangat besar dalam mendukung operasional 
penghimpunan dan penyaluran dana karena keterbatasan wilayah dan sistem operasional pada BMT. Bank Dunia (dalam Hasbullah, 2006:6) mendefinisikan modal sosial sebagai sesuatu yang merujuk ke dimensi institusional, hubungan yang tercipta, dan norma-norma yang membentuk kualitas dan kuantitas hubungan sosial dalam masyarakat. Modal sosial bukan sekadar deretan jumlah institusi atau kelompok yang menopang (underpinning) kehidupan soaial, melainkan dengan spektrum yang lebih luas, yaitu sebagai perekat (social glue) yang menjaga kesatuan anggota kelompok secara bersama-sama.

Hasbullah (2006:9) memilah unsur pokok modal sosial ke dalam enam kategori yaitu: partisipasi dalam satu jaringan, resiprocity, trust, norma sosial, nilai-nilai, dan tindakan yang proaktif. Secara lebih rinci keenam unsur pokok modal sosial akan diuraikan pada alinea-alinea berikut ini. Pertama, partisipasi dalam satu jaringan. Modal sosial akan kuat tergantung pada kapasitas yang ada dalam kelompok masyarakat untuk membangun sejumlah asosiasi berikut membangun jaringannya. Kedua, resiprocity. Modal sosial senantiasa diwarnai oleh kecenderungan saling tukar kebaikan antar individu dalam suatu kelompok atau antar kelompok itu sendiri. Pola pertukaran ini bukanlah sesuatu yang dilakukan secara resiprokal seketika seperti dalam proses jual beli melainkan suatu kombinasi jangka pendek dan jangka panjang dalam nuansa altruism (semangat untuk membantu dan mementingkan kepentingan orang lain). Seseorang atau banyak orang dari suatu kelompok memiliki semangat membantu yang lain tanpa mengharapkan imbalan seketika.

Ketiga, trust atau rasa percaya (mempercayai) adalah suatu bentuk keinginan untuk mengambil risiko dalam hubungan hubungan sosialnya yang didasari oleh perasaan yakin bahwa yang lain akan melakukan sesuatu seperti yang diharapkan dan akan senantiasa bertindak dalam suatu pola tindakan yang saling mendukung, paling tidak yang lain tidak akan bertindak merugikan diri dan kelompoknya. Dalam pandangan Fukuyama (2002:334), trust adalah sikap saling mempercayai di masyarakat tersebut saling bersatu dengan yang lain dan memberikan kontribusi pada peningkatan modal sosial.

Unsur pokok modal sosial yang keempat adalah norma-norma sosial akan sangat berperan dalam mengontrol bentuk-bentuk prilaku yang tumbuh dalam masyarakat. Pengertian norma itu sendiri adalah sekumpulan aturan yang diharapkan dipatuhi dan diikuti oleh anggota masyarakat pada suatu entitas sosial tertentu. Norma-norma ini biasanya terinstutisionalisasi dan mengandung sanksi sosial yang dapat mencegah individu berbuat sesuatu yang akan menyimpang dari kebiasaan yang berlaku di masyarakatnya.

Unsur pokok yang kelima adalah nilai-nilai. Nilai adalah sesuatu ide yang telah turun temurun dianggap benar dan penting oleh anggota kelompok masyarakat. Misalnya, nilai harmoni, prestasi, kerja keras, kompetisi dan lainnya. Akhirnya unsur yang keenam adalah tindakan yang proaktif. Yang dimaksud dengan tindakan yang proaktif adalah anggota pada satu komunitas berusaha melibatkan diri dan mencari kesempatan yang dapat memperkaya hubungan sosial dan menguntungkan kelompok, tanpa merugikan orang lain, secara bersama-sama. 


\section{Metafora Risk-Return untuk Pengembangan Kemandirian BMT}

Metafora risk-return untuk pengembangan kemandirian BMT dimaksudkan untuk menganalisis peran BMT terhadap sektor riil sekaligus mengembangkan BMT sendiri sehingga menjadi lebih mandiri. Analisis risk-return biasanya (hanya) dikaitkan dengan ukuran keuangan melalui rasio-rasio keuangan. Padahal, seperti diuraikan pada latar belakang, BMT memiliki potensi besar (khususnya dibandingkan dengan bank umum) untuk menjangkau sektor riil khususnya usaha kecil dan menengah, dan potensi besar tersebut dapat dikembangkan jika analisis riskreturn diperluas dengan mempertimbangkan hal-hal yang tidak semata-mata berupa rasio keuangan yang telah ada.

Kajian mengenai risk-return pada lembaga keuangan mikro pada saat ini telah menjadi bervariasi, GTZ (2000) yang melihat resiko yang dihadapi lembaga keuangan mikro meliputi resiko finansial, resiko operasional dan resiko strategis namun pada akhirnya tetap saja ditekankan pada pendekatan finansial. Pemaknaan terhadap risk-return ini dapat diperluas pemaknaannya menjadi lebih dari sekedar ukuran keuangan, seperti yang dikemukakan oleh Churchill and Frankiewicz (2006) dimana resiko dikategorikan menjadi resiko institusional, resiko eksternal, resiko operasional dan resiko manajemen finansial.

Demographic risk, macroeconomic risk, environmental risk, dan political risk merupakan resiko yang jauh dari jangkauan atau kontrol dan sulit untuk direspon, sedangkan regulation risk, reputation risk dan competition risk relatif lebih dekat dan bisa direspon oleh lembaga keuangan berskala mikro seperti BMT.

Sementara itu, return biasanya diukur secara nominal atau persen dengan menggunakan rasio keuangan. Secara garis besar, return merupakan hasil atau pendapatan yang diterima dari sebuah investasi, sehingga hasil semestinya tidak harus dalam bentuk nominal namun bisa lebih luas pemaknaannya.

Beberapa return yang diperluas pemaknaannya yaitu, fleksibilitas, pasar yang lebih terpercaya (personal dan sifat partnership), denominasi pembiayaan yang tidak besar dan cenderung diversifikatif (sehingga bisa saling meniadakan/meminimalisir risiko), dan muatan religiusitas pada lembaga keuangan yang mendasarkan kepada syariah

Fleksibilitas BMT tersebut membuka akses bagi pelaku UKM yang tidak bankable untuk mendapat pembiayaan bagi usaha yang dijalankan. Kemudahan syarat dalam mengajukan pembiayaan dan sistem bagi hasil yang dilakukan merupakan keunggulan lain yang dimiliki BMT. Sistem kerjasama yang ditawarkan BMT bagi usaha Kecil dan Menengah mampu melayani usaha kecil dengan skala pinjaman yang ditentukan secara efisien dan menguntungkan kedua belah pihak, baik BMT sendiri maupun peminjam (Zarida, 2004:179).

Realitas tidak 'bankable' pada UKM menyebabkan unit cost yang harus ditanggung Bank Umum menjadi tinggi ketika menyalurkan kredit pada UKM dan membuat Bank Umum tidak tertarik untuk memberikan pinjaman bagi pembiayaan UKM. Kondisi ini pada sisi yang lain memungkinkan bagi BMT untuk memberikan pembiayaan kepada UKM. Dengan kata lain BMT bisa memberikan pembiayaan dengan unit cost yang lebih murah dibanding pada bank konvensional. "Penghematan" unit cost penyaluran kredit/pembiayaan oleh BMT (dibandingkan dengan bank umum) pada sisi yang berbeda dapat dipandang sebagai return potensial yang dapat diperoleh. 


\section{METODE PENELITIAN}

Mendasarkan pada tujuan dari penelitian ini yaitu ingin mengetahui bagaimana metafora risk and return menjadi dasar untuk mengembangkan BMT yang mandiri. Maka penelitian ini menggunakan pendekatan postpositivisme rasionalistik. Dengan tujuan tersebut, penelitian ini akan menjawab bagaimana BMT dapat berkembang secara mandiri dengan mengoptimalkan potensinya. Potensi tersebut jika dikembangkan dengan (hanya) memper-timbangkan risk-return keuangan yang biasa dikembangkan, maka BMT akan sulit bersaing dan bahkan bertahan di industri keuangan. Oleh karena pemaknaan risk-return perlu diperluas sehingga pada gilirannya dapat dirumuskan hal-hal yang dapat menunjang kemandirian BMT. Rumusan tersebut tentu merupakan hasil analisis yang diperoleh dari fenomena/empiri yang muncul di lapang, yang harus difahami dan dianalisis secara holistik. Dengan demikian, kajian yang mendalam melalui pemahaman yang menyeluruh (holistik) terhadap pihak-pihak yang mengalami sendiri (individu pada manajemen dan operasional, serta nasabah BMT) akan menghasilkan rumusan yang dapat menjadi dasar bagi pengembangan BMT yang mandiri.

Metode postpositivisme rasionalistik merupakan pendekatan yang mendasarkan kepada cara berpikir positivistik yaitu berfikir spesifik tentang empiri yang teramati dan terukur. Sementara pendekatan pospositivistik merupakan "penyempurnaan" cara berfikir positivistik dengan analisis pada "proses" (lebih dari sekedar analisis yang mendasarkan kepada "hasil"). Pendekatan postpositivistik ini memiliki karakteristik utama yaitu pencarian makna dibalik data. Dengan metode deduktif yaitu penggunaan teori dan konsep (dalam hal ini regulasi kepegawaian) sebagai acuan awal penelitian, pendekatan positivistik merupakan pilihan yang tepat. Hal ini karena data yang akan dianalisis haruslah data yang teramati dan terukur (sesuai dengan regulasi).

Namun demikian, regulasi bukanlah satu acuan yang bersifat harga mati. Beberapa hal yang ada pada regulasi (undang-uandang/peraturan) bersifat general/umum dan sangat perlu untuk terus dilakukan penyempurnaan sehingga lembaga keuangan syariah (baca: BMT) menjadi lembaga yang berkembang secara mandiri. Analisis yang mendasarkan kepada metafora risk-return (pemaknaan risk-return yang diperluas) merupakan kajian yang harus dilakukan secara mendalam dan menyeluruh. Oleh karena itu pendekatan postposotovistik yang dipilih adalah postpositivisme rasionalistik. Proses penelitian/kajian pada pendekatan postpositivisme rasionalistik menggunakan paradigma kuantitatif dengan metode empirik analitik, tetapi membuat payung berupa grand concept agar data empirik tersebut dapat dimaknai dalam cakupannya yang lebih luas (Muhadjir, 2000). Artinya, kesimpulan, sistem, teori substantif yang dibangun tidak hanya berasal empiri, tetapi juga berasal dari pemahaman intelektual yang dibangun atas kemampuan argumentasi secara logis.

Pengumpulan data dilakukan dengan wawancara mendalam, observasi partisipatif dan dokumentasi. Analisis data dilakukan dengan mengorganisasikan data, mereduksi, mendisplay, dan menyimpulkan, menggambarkan, dan verifikasi data. Mereduksi data berarti merangkum, memilih hal-hal yang pokok, memfokuskan pada hal-hal yang penting, dicari tema dan polanya. Setelah data direduksi maka langkah selanjutnya dengan mendisplaykan data dalam bentuk uraian singkat, bagan, hubungan antar kategori. Selanjutnya langkah-langkah diatas akan mempermudah peneliti dalam melakukan pemaparan dan penegasan kesimpulan. Dari hasil pengumpulan data selanjutnya dilakukan secara kualitatif dengan menggunakan peer debrief- 
ing dilakukan dengan para kolega untuk memperoleh berbagai masukan dan kritik agar kualitas analisis lebih dapat dipertanggungjawabkan. Member check dilakukan dengan para responden/ informan yaitu dengan menanyakan kembali pernyataan yang telah terangkum dalam pemahaman peneliti, untuk memastikan kebenaran makna yang telah dibuat. Makna yang disyaratkan oleh pendekatan postpositivistik rasionalistik adalah kebermaknaan teoritik dan kebermaknaan empirik (Muhadjir, 2000). Kebermaknaan teoritik didasarkan kepada grand concept yang telah disusun, dan kebermaknaan empirik diperoleh melalui peer debriefing dan member check yang dilakukan.

\section{HASIL DAN PEMBAHASAN}

Mendasarkan pada lingkungan internal dan eksternal BMT juga peran penting yang dapat dikembangkan oleh BMT, maka dalam rangka pengembangan kemandirian BMT, menjadi penting untuk menelaah perluasan hakikat dan pengembangan risk \& return dari BMT. Untuk memperoleh informasi mengenai hal tersebut dilakukan observasi pada dua BMT yaitu BMT Amanah yang relatif baru dan BMT Perdana Surya Utama (PSU) yang mempunyai jaringan lebih luas hingga di beberapa kota. Informasi lebih dalam diperoleh melalui wawancara tidak terstruktur pada dua indorman kunci yaitu, Bapak Gandhi dari BMT Amanah dan Ibu Neny dari BMT Perdana Surya Utama (PSU). Hasil observasi dan wawancara tersebut didialogkan dengan beberapa teori perbankan, sehingga risk dan return yang diperluas dapat dijadikan dasar pengembangan untuk kemandirian BMT.

\section{Resiko yang Dihadapi BMT}

Dalam menjalankan operasionalnya sebagian besar lembaga keuangan memfokuskan sumber daya yang dimiliki untuk meminimalkan resiko terutama pada resiko kredit, resiko likuiditas dan resiko pasar (GTZ, 2000). Temuan yang ada, ternyata resiko yang timbul pada operasional BMT disebabkan mayoritas nasabahnya tidak mampu menyediakan jaminan dan ketiadaan sistem penjaminan dana simpanan nasabah.

\section{a. Bentuk Jaminan yang Diperluas}

Pangsa pasar yang menjadi target penyaluran pembiayaan oleh BMT mayoritas adalah masyarakat perekonomian menengah kecil termasuk sektor usaha kecil menengah (UKM). Pembiayaan BMT yang diperuntukkan kalangan tersebut menuntut perlakuan khusus jika dibanding pembiayaan yang dilakukan oleh perbankan, terutama pada bentuk jaminan atau garansi untuk pembiayaan. Jika pada sistem perbankan menuntut bentuk jaminan untuk pembiayaan berupa materiil, maka hal tersebut tidak dapat diterapkan pada pembiayaan untuk sektor UKM. Keterbatasan aset yang dimiliki merupakan penyebab utama ketidakmampuan sektor UKM untuk menyediakan jaminan seperti yang disyaratkan lembaga perbankan.

Kelemahan yang dimiliki sektor UKM dalam hal penyediaan jaminan tidak sekaligus menghilangkan potensi dan prospektif yang ada pada sektor tersebut. Memahami kondisi tersebut lembaga pembiayaan BMT berusaha mengakomodir kondisi pada sektor UKM dengan memperluas bentuk jaminan tidak hanya berwujud materil namun jaminan bisa bersifat immateril. Bentuk jaminan yang diperluas tersebut terungkap dari penjelasan Ibu Neny sebagai berikut: 
"untuk setiap bentuk peminjaman itu harus ada baik itu berupa surat berharga maupun dengan menggunakan personal garansi sebagai pengganti dari surat berharga untuk peminjaman yang rendah. Biasanya memang untuk pengusaha kecil kan belum semua memiliki barang berharga seperti contohnya motor untuk menjadi jaminan, maka mereka bisa menggunakan personal garansi tersebut. Tetapi total pinjaman yang kita berikan juga tidak terlalu besar sekitar lima ratus ribu sampai dengan satu juta rupiah seperti itu. Untuk setiap peminjaman yang tidak memiliki asset yang dapat dijaminkan mereka harus mempunyai personal garansi untuk bertanggung jawab apabila ada kemacetan dalam pembiayaannya”.

Dari pernyataan Ibu Neny, bahwa untuk pinjaman dalam jumlah tertentu dimungkinkan nasabah tidak memberikan jaminan berupa aset berwujud, namun digantikan dengan adanya personal garansi. Dalam realitasnya, kesanggupan untuk menjadi personal garansi sangat dipengaruhi oleh kepercayaan dan penilaian garantor terhadap karakter dan kredibilitas calon nasabah. Dalam bisnis faktor yang menentukan terbentuknya suatu hubungan bisnis adalah nama baik atau kredibilitas, yang berarti tidak mempunyai rekam jejak wan prestasi. Dengan demikian, nama baik bisa dikategorikan sebagai aset yang tidak berwujud (intangible asset), sehingga bisa menjadi bentuk jaminan. Metode untuk menilai apakah seseorang tersebut kredibel atau tidak, dilakukan dengan mensurvey tempat tinggal atau tempat usahanya, mencari informasi di lingkungannya, seperti penjelasan dari Pak Gandhi berikut ini:

"Jadi lebih pada prinsip syariah, kita lihat usahanya halal-haramnya, kita lihat sekitarnya, kemampuannya, sikapnya, kalau semua baik dan amanah itu semua kita bisa memberikan".

Sedangkan penilaian karakter calon nasabah khususnya nasabah yang baru, pada praktiknya dilakukan dengan menggunakan intuisi atau naluri. Hal tersebut terungkap dari keterangan Pak Gandhi sebagai berikut:

"Ya itu tadi mas, saya hanya mengutamakan dipandu dengan rasa naluri dan amanah. Tidak asal 1 bulan - 2 bulan kita lihat apakah ada perkembangan, Jadi kita itu sambil merasakan apakah bantuan keuangan yang kita sampaikan dapat memberikan nilai positif tidak terhadap yang kita bantu”.

Lebih lanjut Pak Gandhi menyampaikan :

"Kita lebih menilai dengan naluri, jadi misal tidak sesuai dengan personalitynya kita akan kembalikan kesana pasti akan terasa. Siapapun yang datang ke kita, akan ditanggapi dengan naluri. Misal semua sudah, akan tetapi ada beberapa yang tidak lengkap ya tidak akan kita proses”.

Fungsi nama baik sebagai jaminan memang hanya bisa menjadi kendali bagi peminjam agar tidak melakukan moral hazard, karena jika sampai dilakukan maka akan membatasi akses ke sumber pendanaan di masa mendatang. Sebaliknya jika nasabah dapat membuktikan kredibilitasnya selama jangka waktu pembiayaan, maka untuk kebutuhan pembiayaan selanjutnya lebih mudah untuk mendapatkannya. Sedangkan fungsi jaminan untuk menutup kerugian sebagaimana lazimnya di sistem perbankan, tidak dapat dipenuhi oleh bentuk jaminan yang sifatnya immateril. 
Strategi BMT untuk mengakomodir kebutuhan pembiayaan di sektor UKM dengan memperluas bentuk jaminan, akan meningkatkan jumlah penyaluran pembiayaan sekaligus menjadi kekuatan dalam persaingan dengan lembaga keuangan lain khususnya perbankan. Namun sebagaimana dijelaskan sebelumnya bahwa jaminan yang berbentuk immateril (baca : nama baik) tidak bisa menjadi sumber untuk menutup kerugian yang mungkin terjadi, maka bisa dianggap BMT mengalami trade off antara peningkatan pendapatan melalui penetrasi di sektor UKM dengan peningkatan resiko yang timbul dari perluasan bentuk jaminan.

\section{b. Ketiadaan Fasilitas Penjaminan Dana Nasabah}

Motivasi individu menyimpan dananya di lembaga keuangan bisa berasal dari berbagai macam kebutuhan, dari kebutuhan layanan lalu lintas pembayaran hingga kebutuhan berinvestasi. Berbagai macam kebutuhan nasabah depositor tersebut mempunyai tuntutan yang sama yaitu keamanan dana yang disimpan. Pada lembaga keuangan seperti BMT, dimana keberadaannya belum didukung oleh sarana dan prasarana untuk jasa pelayanan keuangan yang mutakhir maka kegiatan operasional BMT hanya berupa layanan simpanan dan pembiayaan. Keterbatasan layanan BMT tersebut menyebabkan pasarnya tersegmentasi (terbatas), yaitu pada investor yang mengharapkan imbal jasa yang kompetitif sekaligus keamanan dana investasinya. Dari sudut pandang penghimpunan dana maka portofolio sumber dana menjadi kurang optimal. Ironisnya, dengan tipe nasabah yang dimiliki tersebut BMT belum memiliki perlindungan simpanan nasabah (penjaminan resiko bagi nasabah) seperti yang dimiliki Bank Umum. Sementara dari sisi penyaluran dana, pihak BMT juga tidak mempunyai perlindungan asuransi untuk pembiayaan yang diberikan. Padahal pembiayaan oleh BMT lebih banyak terserap di sektor UKM yang kondisinya relatif rentan terhadap kondisi pasar. Kondisi yang kurang lebih sama juga terjadi pada lembaga keuangan mikro lainnya (non syariah) seperti yang diungkap oleh Untoro (2005) bahwa ternyata mayoritas lembaga keuangan mikro tidak bekerjasama dengan lembaga penjamin kredit (asuransi) seperti PT. Penjaminan Kredit Pengusaha Indonesia (PKPI), PT. Asuransi Kredit Indonesia (ASKRINDO), dan Asuransi Ekspor Indonesia (ASEI), Perum Sarana, PT. Perum Pengembangan Koperasi.

Dari 2 hal yaitu ketiadaan sistem penjaminan dana nasabah dan mayoritas penyaluran pembiayaan pada sektor yang rentan mengakibatkan resiko yang dihadapi BMT relatif lebih tinggi dibanding Bank Umum. Belum tersedianya sistem penjaminan dana nasabah pada operasional lembaga keuangan yang di luar naungan Bank Indonesia (misal : BMT) mengakibatkan BMT harus berusaha lebih 'keras' dalam melaksanakan manajemen resiko untuk menjaga keamanan investasi. Upaya yang dilakukan pihak BMT dalam mengamankan dana nasabah sangat terkait dengan upaya pemeliharaan pembiayaan yang disalurkan agar tidak menjadi investasi yang merugikan. Adapun upaya-upaya yang dimaksud seperti yang diungkapkan Ibu Neny berikut ini:

"Kami menggunakan pengawasan bersama dimana di dalamnya ada yang diistilahkan personal garansi,kemudian kita cek ke lapangan, jika benar maka dilakukan condolasan tanpa mediasi supaya tidak terlilit utang".

Fakta bahwa lembaga keuangan di luar sistem perbankan (misal :BMT) belum dilengkapi dengan sistem penjaminan dana nasabah, menjadi kendala dalam mengoptimalkan penghimpunan 
dana karena keamanan dana merupakan salah satu tuntutan nasabah deposan, seperti yang terungkap dari penjelasan lebih lanjut dari Ibu Neny sebagai berikut:

“...ada nasabah kemarin juga menanyakan bagaimana jaminan keamanan dana yang ada disini, itu dari kami pihak BMT mencoba menjelaskan serasional mungkin kepada nasabah. Bahwa setiap usaha pasti ada risiko, dan pihak BI pun memberikan jaminan terbatas ya pasti ada batasnya. Bank sekelas Century saja pun BI tidak bisa mengatasi masalah tersebut. Jadi intinya kita memberikan pengertian bahwa kami berusaha penuh untuk menjamin keamanan tersebut, salah satunya dengan personal garansi itu tadi”.

Dengan adanya kendala sistemik seperti penjelasan sebelumnya, mengakibatkan lembaga keuangan non perbankan seperti BMT tidak bisa optimal dalam menghimpun dana dari masyarakat. Sedangkan dari sisi penyaluran dana, target pasar yaitu sektor UKM sangat besar jumlahnya. Kondisi yang terjadi pada kegiatan penghimpunan dana serta penyalurannya, memberikan fakta bahwa terjadi kekurangan sumber dana pada BMT. Sebagai upaya agar tidak kehilangan pendapatan potensial dari sektor UKM, maka BMT kemudian menjadi retailer dari lembaga perbankan syariah yang notabene mempunyai sumber dana lebih besar. Posisi BMT sebagai retailer atau agen pada hubungan kerjasama dengan bank umum syariah menimbulkan ketidakmandirian pada BMT karena ketergantungan sumber dana untuk operasional.

Hubungan kerjasama yang memposisikan BMT sebagai retailer dengan Bank Umum Syariah sebagai pemilik dana, memang merupakan jalan pintas yang menguntungkan dalam situasi kekurangan sumber dana. Namun untuk kepentingan jangka panjang, situasi demikian akan menjadikan BMT tergantung terus menerus kepada bank umum sebagai sumber pendanaan.

\section{Pemaknaan Return yang Diperluas}

Pada umumnya return (imbal jasa) dari suatu investasi keuangan diukur secara nominal atau dalam persen. Salah satu pengertian return (bank) adalah semua pendapatan yang merupakan hasil langsung dari kegiatan usaha bank yang benar-benar telah diterima. Yang termasuk dalam pendapatan ini adalah hasil bunga (bagi hasil pada bank syariah, pen), provisi dan komisi, pendapatan valas, dan pendapatan lainnya (Siamat, 1993: 251). Namun pemaknaan terhadap risk-return ini dapat diperluas pemaknaannya menjadi lebih dari sekedar ukuran keuangan, seperti yang dikemukakan oleh Churchill and Frankiewicz (2006).

Secara lebih rinci, yang dimaksud return yang diperluas adalah lebih dari sekedar return konvensional (bagi hasil pembiayaan) tetapi, berkembang ke beberapa hal yang dimaknai sebagai return, antara lain loyalitas nasabah, jaringan, dan berkembangnya fungsi sosial bagi BMT.

\section{a. Loyalitas Nasabah dan Implikasinya Terhadap Kontinuitas Usaha/Pembiayaan}

Hubungan bisnis yang didasarkan pada kesamaan religiusitas dan kedekatan emosional pada akhirnya membentuk kepercayaan (trust). Seperti pengertian trust pada Francois (2003) dalam Hasbullah (2006:11) yang memandang trust sebagai "kelompok ekonomi yang relevan melekat pada kultur yang ada pada masyarakat yang akan membentuk kekayaan modal sosial." Maka kepercayaan tersebut adalah unsur pokok yang terdapat di antara lembaga keuangan (BMT) dan pihak nasabah. Tanpa adanya kepercayaan, tidak mungkin nasabah mendapatkan dana dari pihak BMT. Kemudian dalam proses selanjutnya, perasaan mendapat 
kepercayaan dari pihak BMT dimana hal tersebut tidak didapatkan dari lembaga keuangan lain (perbankan) akan menimbulkan loyalitas pada diri nasabah. Dalam hal ini loyalitas dalam memanfaatkan layanan jasa keuangan dari BMT. Nasabah cenderung memanfaatkan layanan BMT (pembiayaan) secara berkelanjutan, artinya setelah satu akad pembiayaan selesai nasabah akan memanfaatkan lagi jasa pembiayaan untuk pengembangan usaha atau kebutuhan yang lain. Fakta tersebut sebagaimana yang dituturkan oleh Pak Gandhi berikut ini:

"Tapi ada yang karena silaturahminya itu terjaga dan bagus minta untuk dibiayai menambah maju membangun bagus toko, modal untuk kulakan dan sebagainya".

Penjelasan informan (Pak Gandhi) sejalan dengan temuan pada BMT Dana Syariah dalam Kholis (2009) mengenai fase setelah pembiayaan

1). Melakukan pendekatan secara lebih intensif dengan cara mengunjungi nasabah secara berkala (silaturahmi)

2). Menawarkan pembiayaan baru kepada nasabah yang mempunyai rekam jejak pembiayaan yang baik

Manifestasi loyalitas nasabah dengan memanfaatkan jasa BMT secara berkelanjutan ditinjau dari sisi BMT merupakan sumber pendapatan potensial. Dengan adanya pola hubungan antara nasabah dan BMT yang berlandaskan trust sehingga menimbulkan loyalitas nasabah, berdampak positif bagi kontinuitas pembiayaan dan usaha dari BMT.

\section{b. Loyalitas Nasabah dan Implikasinya Terhadap Turnover Dana}

Skim pembiayaan yang spesifik seperti yang diberikan oleh BMT, memang ditujukan untuk target pasar yang spesifik juga, dimana tipe nasabah tersebut tidak bisa terlayani oleh sistem yang ada pada lembaga keuangan perbankan. Sejalan dengan pendapat Kholis (2009) Penting untuk digarisbawahi bahwa mudahnya akses terhadap suatu skema pembiayaan dianggap lebih bermanfaat dibandingkan dengan subsidi tingkat bunga. Sektor ekonomi lemah lebih menginginkan skema pembiayaan yang sederhana dan cepat.

Kondisi demikian secara alami akan berpotensi bagi BMT membentuk loyalitas nasabah. Namun menurut Wellman (1983:156-157) dalam Ritzer dan Goodman (2004:383) yaitu:

“...aktor dan perilakunya dipandang sebagai dipaksa oleh struktur sosial ini. Jadi, sasaran perhatian analisis jaringan bukan pada aktor sukarela, tetapi pada paksaan struktural".

Artinya, kondisi nasabah yang tidak bankable sehingga hanya bisa terlayani oleh lembaga keuangan seperti BMT, sebenarnya bisa dimaknai sebagai paksaan struktural.

Pada praktiknya jumlah pembiayaan untuk masing-masing nasabah BMT relatif kecil dibandingkan pada sistem perbankan, sementara tujuan pembiayaan sebagian besar untuk usaha dengan tipe usaha yang perputaran dananya relatif pendek. Untuk mengakomodir kebutuhan pembiayaan yang demikian maka jangka waktu pembiayaan dirancang dengan untuk termin waktu yang sangat fleksibel. Demikian juga untuk periode angsuran juga fleksibel tergantung aliran kas dari usaha. Faktor jumlah pembiayaan tiap nasabah yang kecil, jangka waktu pinjaman yang pendek dan periode angsuran yang fleksibel, mengakibatkan tingginya perputaran dana (turnover) pada operasional BMT. 


\section{c. Perluasan Pasar Yang Diperoleh Dari Jaringan Yang Bersifat Personal Pada Operasional BMT}

Dalam mencari nasabah baik untuk penghimpunan dana maupun penyaluran dana, pihak BMT menggunakan metode pendekatan personal pada komunitas-komunitas tertentu, dengan kesamaan nilai sebagai titik masuk ke dalam komunitas tersebut. Dengan adanya kesamaan nilai akan memungkinkan terjadinya interaksi yang pada gilirannya akan menumbuhkan 'ikatan' di antara BMT dengan nasabahnya. Proses tersebut sejalan dengan pendapat Wellman (1983:156157) dalam Ritzer dan Goodman (2004:383) yaitu:

"Analisis jaringan memulai dengan gagasan sederhana namun sangat kuat, bahwa usaha utama sosiolog adalah mempelajari struktur sosial...cara paling langsung mempelajari struktur sosial adalah menganalisis pola ikatan yang menghubungkan anggotanya. Pakar analisis jaringan menelusuri struktur bagian yang berada di bawah pola jaringan biasa yang sering muncul ke permukaan sebagai sistem sosial yang kompleks..."

Masih di dalam Ritzer dan Goodman (2004:383), Granoveter (1973:1983) menambahkan bahwa dalam jaringan terdapat "kekuatan ikatan". Dengan cara demikian, memudahkan BMT untuk membuat jejaring yang berdampak positif untuk perluasan pasar BMT. Dari segi biaya pemasaran, keberadaan jejaring yang telah terbentuk sangat bermanfaat bagi penghematan biaya.

\section{d. Fungsi Sosial Sebagai Amil Dapat Lebih Tepat Sasaran Dalam Menyalurkan ZIS (Karena Sifat Personal Dalam Operasional)}

Salah satu pondasi hubungan antara BMT sebagai sebuah lembaga dengan nasabahnya, adalah shared value pada religiusitas sehingga hubungan yang terbentuk tidak sekedar bersifat bisnis karena telah terbentuk kedekatan emosional. Adanya kedekatan tersebut menjadikan layanan BMT menjadi lebih personal, salah satunya layanan yang terkait dengan kebutuhan untuk melaksanakan ibadah berupa pemberian zakat, infaq maupun sodaqoh. Layanan yang diberikan BMT terkait dengan kebutuhan ibadah nasabahnya, salah satunya terungkap dari penjelasan Ibu neny sebagai berikut:

"Untuk nasabah yang memiliki jumlah bagi hasil di atas 10.000 ini 2,5\% nya kita potong kita kumpulkan nanti diakumulasi 1 tahun lebaran begini kita bagikan ke kaum dhuafa. Hasil dari pemotongan zakat tadi, seperti itu”.

Selain itu karena hubungan yang personal, maka BMT lebih mudah memastikan kelayakan calon mustahiq yang akan menerima ZIS ataupun qordul hasan (pinjaman kebajikan). Misalkan nasabah yang hendak memulai usaha yang benar-benar baru dan tidak mempunyai aset yang menunjang usaha barunya, maka baginya berhak memperoleh qordul hasan.

\section{Penerapan Strategi Untuk Manajemen Resiko Pada Penjaminan}

Ketiadaan jaminan yang bisa digunakan sebagai sumber pendanaan untuk menutup kerugian pada penyaluran pembiayaan, menuntut BMT untuk menciptakan suatu strategi manajemen resiko yang spesifik sehingga bisa mengendalikan resiko pembiayaan untuk sektor UKM. Strategi 
yang dilakukan salah satunya dengan mensyaratkan adanya personal garansi untuk setiap pembiayaan yang diberikan. Perihal personal garansi dalam pembiayaan terungkap dari jawaban Ibu neny berikut ini:

"Maksudnya misalnya nasabah kami, akan mengajukan pembiayaan, nah saya dimaksud sebagai personal garansi, jadi ketika nasabah tersebut tidak mampu membayar, yang harus membayar dan bertanggung jawab adalah personal garansinya".

Posisi personal garansi dalam praktik perbankan adalah seseorang yang akan bertanggung jawab secara finansial kepada pihak bank ketika debitur yang digaransi melakukan wan prestasi. Oleh karenanya pihak yang menjadi personal garansi tentunya telah mengenal karakter dan percaya terhadap kapasitas pihak yang digaransi, selain itu personal garantor juga harus mempunyai kemampuan dan kesanggupan untuk bertanggung jawab secara finansial. Persyaratan untuk menghadirkan personal garansi dengan kondisi seperti yang dijelaskan sebelumnya, menjadi kendala bagi debitur dari sektor UKM. Berhadapan dengan kondisi demikian sebagai jalan keluar maka BMT membuat kebijakan bahwa yang menjadi personal garantor bagi nasabah adalah karyawan BMT yang merekomendasi nasabah yang mendapatkan pembiayaan, seperti yang diungkapkan Ibu Neny berikut ini:

“...yang berhak menjadi personal garansi itu biasanya pengurus BMT, Penanam saham dan bahkan seluruh karyawan disini wajib menjadi personal garansi dari nasabah, apabila ada apa-apa gaji kami yang terpotong".

Konsekuensi keuangan yang harus ditanggung sebagai personal garantor berdampak pada perilaku karyawan untuk lebih berhati-hati dalam menganalisis kelayakan pembiayaan sekaligus meningkatkan intensitas monitoring terhadap debitur. Pada dasarnya kebijakan mengenai kewajiban karyawan untuk menjadi personal garansi merupakan implementasi manajemen resiko sebagai lembaga keuangan. Selain itu, implementasi manajemen resiko juga dilakukan melalui pembatasan besarnya kredit tanpa jaminan aset berwujud, seperti yang dijelaskan Ibu Neny sebagai berikut :

"Biasanya memang untuk pengusaha kecil kan belum semua memiliki barang berharga seperti contohnya motor untuk menjadi jaminan, maka mereka bisa menggunakan personal garansi tersebut. Tetapi total pinjaman yang kita berikan juga tidak terlalu besar sekitar lima ratus ribu sampai dengan satu juta rupiah seperti itu."

Faktor penentu untuk menilai apakah calon debitur layak untuk mendapatkan pembiayaan adalah karakter calon debitur. Proses pencarian informasi yang dibutuhkan untuk penilaian karakter tersebut bagi sistem lembaga keuangan BMT relatif lebih mudah dan lebih reliable dibanding pada sistem perbankan, karena operasional BMT lebih bersifat personal dan mengandalkan kedekatan emosional (kesamaan religius).

\section{Penerapan Strategi untuk Penghimpunan Dana}

Beberapa strategi yang dapat dikembangkan terkait dengan penghimpunan dana yaitu,

Pertama, pelonggaran syarat yang bersifat administratif sehingga jika dibandingkan dengan syarat untuk produk simpanan pada bank umum, nasabah merasa lebih ringan dan diharapkan 
tertarik untuk menyimpan dana di BMT. Hal tersebut terungkap dari penjelasan Ibu Neny sebagai berikut:

"Kelebihan BMT ini saldo minimal 10.000 bisa dan tidak dipotong apabila vakum transaksi selama 6 bulan berturut-turut. Itu tetap ada tidak hangus. Kan biasanya yang lain seperti itu karena harus terpotong biaya administrasi setiap bulannya ya mbak, di kami tidak. Jadi misal buka terus tidak melakukan apa-apa atau kelupaan tahun depan dibuka masih ada insya Allah".

Strategi pelonggaran syarat administratif tersebut termasuk penghapusan pajak, seperti yang dijelaskan oleh Ibu Neny sebagai berikut:

"Jadi penyesuaiannya seperti ini sistemnya tanpa biaya administrasi setiap bulan, hanya dikenakan administrasi di awal pembukaan dan tutup. Termasuk pajak biaya administrasi ini tidak ada kita kenakan".

Penyederhanaan atau pelonggaran syarat administratif berimplikasi pada pengurangan biaya transaksi dari sisi nasabah depositor. Dalam konteks makro pengurangan biaya transaksi di sektor keuangan mendorong efisiensi produksi di sektor riil.

Kedua, menjalin hubungan dengan mendasarkan pada kesamaan keyakinan (religiusitas) pada target pasar yang potensial. Proses tersebut merupakan tahap akumulasi modal (modal sosial) yaitu untuk mendapatkan kepercayaan dan shared value. Dalam praktiknya untuk menjalin hubungan baik dengan nasabah maupun yang menjadi nasabah potensial, BMT secara aktif mendatangi kegiatan-kegiatan yang bersifat religius yang diadakan oleh komunitas tertentu dan mendatangi secara personal ke rumah-rumah. Hal tersebut dijelaskan oleh Ibu Neny sebagai berikut:

"Untuk hal itu kita lebih sering dengan pendekatan personal ya, jadi datang ke majelis ta'lim dan seterusnya kita berikan informasi. $80 \%$ nasabah ini dibangun dengan ikatan emosional yang kuat. Di kami juga biasa main ke rumah kita informasikan, disini ada ya tim marketing kami demikian jadi dimulai dari orangorang terdekat terlebih dahulu. Apa ya semacam ada kedekatan begitu dengan nasabah kita".

Sejalan dengan berbagai konsep mengenai modal sosial yang dikemukakan Hasbullah yaitu partisipasi dalam satu jaringan, resiprocity, trust, norma sosial, nilai-nilai, dan tindakan yang proaktif akan memberi gambaran bagaimana sebuah kerja sama/ jaringan (baca: kontrak usaha tani) dapat berlangsung (mungkin berkali-kali) bukan semata-mata pertimbangan rasional semata tetapi juga dibangun oleh hubungan sosial yang terjadi di antara mereka. Hubungan sosial itu bisa digambarkan melalui nilai-nilai atau norma-norma yang disepakati sehingga memunculkan kepercayaan diantara mereka.

Kepercayaan sangat bermanfaat sebagai filter pertama untuk sebuah hubungan kerjasama, terbentuknya kepercayaan itu sendiri banyak disokong oleh karakter dari kedua belah pihak. Sementara shared value dapat terbentuk dari alasan religiusitas. Artinya masing-masing pihak memaknai religiusitas sebagai nilai lebih sebuah kegiatan ekonomi (baca: akad penghimpunan maupun pembiayaan). Nilai lebih tersebut misalkan nilai ibadah, lebih dari sekedar nilai ekonomis/ bisnis. Ketika sebuah hubungan/akad/kontrak dilandasi oleh shared value tersebut, 
maka berjalannya dan penegakan kontrak menjadi lebih mudah, seperti yang dijelaskan oleh Ibu Neny sebagai berikut:

“...kemarin beberapa waktu lalu saya presentasi di SD di Blimbing itu menawarkan produk Sipintar tabungan untuk siswa. Ternyata sebelum ini sudah ada Mandiri, sama persis, Cuma kalau disana 10.000, kita mulai 5.000, ini yang bagaimana ya, jadi persaingan itu ketat. Tapi karena kedekatan emosional dengan kepala sekolah yang ada ya bisa goal".

Dua bentuk modal sosial yaitu kepercayaan dan shared value menjadi 'pelumas' pada setiap proses dan/atau akad yang dijalankan baik dalam penghimpunan dana sekaligus penyaluran pembiayaan. (Manzilati, 2009) Teori tersebut terbukti pada realitas yang terjadi ketika pihak BMT bersaing dengan Bank Mandiri yang notabene merupakan pesaing yang mempunyai sumberdaya yang relatif lebih, ternyata bisa dikalahkan, dikarenakan pihak BMT telah mempunyai modal kepercayaan dari calon nasabahnya.

Ketiga, pelayanan lebih di selain penjaminan nasabah. Ketiadaan sistem penjaminan dana nasabah yang merupakan tuntutan nasabah merupakan kelemahan BMT dalam menghadapi persaingan dengan lembaga perbankan. Sebagai usaha untuk survive dalam persaingan dengan lembaga perbankan, BMT berusaha memanfaatkan potensi yang dimiliki yaitu sifat layanan yang lebih personal dengan nasabahnya. Salah satu contoh adalah sistem hadiah umroh bagi bagi nasabah deposan yang dirancang sedemikian rupa sehingga mempunyai nilai lebih.

Pemberian hadiah berupa pemberangkatan untuk ibadah umroh tidak sekedar memberikan pembiayaan namun dalam prosesnya juga diadakan kegiatan religius (baca : pengajian) dan pemberangkatannya juga dirancang sedemikian rupa sehingga mempunyai nilai lebih, seperti yang dikemukakan Ibu Neny berikut ini:

"Iya ada beberapa produk yang kami beri hadiah. Terakhir BMT ada produk Si Berkah, jadi, setiap 6 bulan kita adakan pengajian, disitu ada grandprize umroh. ...Emm 45 bulan, jadi per 6 bulannya kita undi ada nomor undangan itu yang kita ambil, baru diakhir berangkat bersama, kemarin ada 44 jamaah kita berangkatkan".

Pelayanan yang demikian secara psikologis berdampak positif mempererat hubungan antara BMT dengan nasabahnya lebih dari sekedar hubungan bisnis, hal positif tersebut kemungkinan besar akan disebarluaskan dan menjadi nilai tambah yang menarik para calon nasabah deposan.

\section{E. KESIMPULAN}

Konsep resiko dan return yang diperluas adalah risk dan return konvensional (keuangan) dan risk dan return yang sifatnya non keuangan. Resiko yang dihadapi BMT secara lebih luas dapat dipilah ke dalam bentuk jaminan dan fasilitas penjaminan dana nasabah.

Bentuk Jaminan pada BMT harus mendasarkan pada konsep bahwa jaminan hanya diperbolehkan untuk menghindarkan dari perilaku moral hazard tidak untuk mengkompensasi resiko investasi yang dilakukan. Sehingga BMT harus mengembangkan bentuk jaminan yang tidak berupa aset fisik. Dalam hal ini BMT Amanah dan PSU menempatkan nama baik sebagai jaminan (intangible asset), itupun hanya untuk pembiayaan kecil. Belum tersedianya sistem penjaminan dana nasabah pada operasional lembaga keuangan yang di luar naungan Bank Indo- 
nesia (misal : BMT) mengakibatkan BMT harus berusaha lebih 'keras' dalam melaksanakan manajemen resiko untuk menjaga keamanan investasi.

Sedangkan dari sisi return, pemaknaannya diperluas disamping return keuangan pada loyalitas nasabah, perluasan pasar dan berjalannya fungsi sosial BMT. Skema pembiayaan yang spesifik ditujukan untuk target pasar yang tidak bisa terlayani oleh sistem lembaga keuangan perbankan menjadi salah satu faktor yang membentuk loyalitas nasabah disamping faktor religiusitas. Manifestasi loyalitas nasabah berupa pemanfaatan jasa BMT secara berkelanjutan merupakan sumber pendapatan potensial dan berdampak positif bagi kontinuitas pembiayaan dan usaha dari BMT. Faktor jumlah pembiayaan tiap nasabah yang kecil, jangka waktu pinjaman yang pendek dan periode angsuran yang fleksibel, mengakibatkan tingginya perputaran dana (turnover) pada operasional BMT.

Perluasan pasar yang diperoleh dari jaringan yang bersifat personal pada operasional BMT merupakan return berupa 'penghematan' biaya promosi dan pencarian nasabah baru. Sementara fungsi sosial sebagai amil, karena sifat personal dalam operasional, dapat lebih tepat sasaran dalam menyalurkan ZIS.

Beberapa hal yang dilakukan BMT untuk menyikapi hambatan dan tantangan menuju kemandirian adalah penerapan sistem personal garansi, pelonggaran syarat yang bersifat administratif, menjalin hubungan dengan mendasarkan pada kesamaan keyakinan (religiusitas) pada target pasar yang potensial, dan pelayanan lebih di selain penjaminan nasabah.

\section{DAFTAR PUSTAKA}

2000. A Risk Management Framework for Microfinance Institutions. Division 41 Financial Systems Development. Deutsche Gesellschaft für Technische Zusammenarbeit (GTZ)

Adiprigandani, Siti. 2005. Metode Penelitian Kualitatif. Diktat Workshop Metode Riset Kualitatif: Konsep dan Aplikasi. LSM Fakultas Ekonomi Universitas Indonesia, tidak dipublikasikan.

Churchill and Frankiewicz. 2006. Making Microfinance Work. Managing for Improved Performance. International Labour Organization.

Hasan, Iqbal. 2002. Pokok-Pokok Materi Metode Penelitian dan Aplikasinya. Jakarta: Ghalia Indonesia.

Hasbullah, Jousairi.2006. Social Capital: Menuju Keunggulan Budaya Manusia Indonesia. MR-United Press: Jakarta.

Mishkin, Frederic S and Stanley J. Eakins. 2000. Financial Market and Institution. EddisonWesley. USA

Kholis, Nur. 2009. The Contribution Of Islamic Microfinance Institution In Increasing Social Welfare In Indonesia (A Case Study Of Bmt's Role At Pakem Market Micro Traders Yogyakarta)

Lin, Nan. 2002. Social Capital; A Theory of Social Structure and Action. Cambridge University Press. United Kingdom. 
Manzilati, Asfi. 2009. Institutional Arrangement Kontrak Usaha Tani Dalam Kerangka Persoalan Keagenan dan Implikasinya Terhadap Keberlanjutan Usaha Tani. Disertasi di Program Doktor Ilmu Ekonomi Universitas Brawijaya. Tidak Dipublikasikan

Mu'alim, Amir dan M. Zainal Abidin. 2005. Profesionalisme Praktisi BMT di Kota Yogyakarta dan Kabupaten Sleman. Millah, Vol. IV, (No. 2).

Muhadjir, Noeng. 2000. Metode Penelitian Kualitatif. Edisi IV. Rake Sarasin, Yogyakarta.

Nadjib, Mochamad dan Mahmud Thoha. 2006. Pengaruh Baitul Maal Wat Tamwil (BMT) Terhadap Kondisi Sosial Ekonomi Masyarakat.

Nimal A. Fernando. 2008. Managing Microfinance Risks Some Observations and Suggestions. Asian Development Bank.

Panggabean, Riana. 2008. Kerjasama Bank, Koperasi dan Lembaga Keuangan Mikro (LKM) Mendukung Pemberdayaan Usaha Mikro Kecil dan Menengah (UMKM). www.smecda.com/deputi7/file_Infokop/VOL15.../4_\%20Riana.pdf. Diakses tanggal 27 Maret 2010.

Ritzer, George and Goodman, Douglas. 2003. Sociological Theory. Sixth Ed. McGraw-Hill.

Sakai, Minako and Marijan, Kacung. 2008. Mendayagunakan Pembiayaan Mikro Islami. Policy Brief 9. Crawford School of Economics and Government, Australian National University.

Siamat, Dahlan. 1993. Manajemen Bank Umum. Intermedia. Jakarta.

Situmorang, Jannes. tt. Kaji Tindak Peningkatan Peran Koperasi dan UM Sebagai Lembaga Keuangan Alternatif. Laporan penelitian tentang aspek kelembagaan dan keuangan usaha BMT di 9 (sembilan) propinsi yang meliputi : Sumatera Selatan, Lampung, Jawa Barat, Jawa Tengah, D.I. Yogyakarta, Jawa Timur, Bali, NTB dan Sulawesi. http://www.scribd.com/doc/39146258/ BMT-UMK diakses tanggal 25 Maret 2010.

Sugiyono. 2007. Memahami Penelitian Kualitatif. ALFABETA. Bandung.

Suhendi, Hendi. 2009. Strategi Optimalisasi Peran BMT Sebagai Penggerak Sektor Mikro. http:// www.fe.unpad.ac.id/forumdekan2009/downloads/p hendi.pdf. diakses tanggal 10 Maret 2010.

Untoro dan Warjiyo, Perry. 2005. Default Risk dan Penjaminan Kredit UKM. Buletin Ekonomi Moneter dan Perbankan.

Wijono, Wiloejo Wirjo. 2009. Pemberdayaan Lembaga Keuangan Mikro Sebagai Salah Satu Pilar Sistem Keuangan Nasional : Upaya Konkrit Memutus Mata Rantai Kemiskinan. http:// www.slideshare.net/putramalaka/lembaga-keuangan-mikro. diakses tanggal 10 Maret 2010.

Zarida. 2004. Pemberdayaan Usaha Kecil Menengah Model Baitul Mal Wat Tamwil. www.katalog.pdii.lipi.go.id/index.php/searchkatalog/.../4796/4797.pdf., diakses tanggal 25 Maret 2010. 